\title{
Movements of juvenile and sub-adult striped bass Morone saxatilis in the Saint John River, New Brunswick, Canada
}

\author{
S. N. Andrews ${ }^{1, *}$, T. Linnansaari ${ }^{1,2}$, N. M. Leblanc ${ }^{3}$, S. A. Pavey ${ }^{3}$, R. A. Curry ${ }^{1,2}$ \\ ${ }^{1}$ Canadian Rivers Institute, Department of Biology, ${ }^{2}$ Faculty of Forestry and Environmental Management, \\ University of New Brunswick, PO Box 4400, Fredericton, New Brunswick E3B 5A3, Canada \\ ${ }^{3}$ Canadian Rivers Institute, Biological Sciences Department, University of New Brunswick Saint John, 100 Tucker Park Rd., \\ Saint John, New Brunswick E2L 4L5, Canada
}

\begin{abstract}
Juvenile striped bass (age-1) of distinct genetic ancestry were re-discovered in the Saint John River, New Brunswick in 2014 after a 35 yr hiatus of recognition. These juveniles were determined to be highly genetically divergent from all possible source populations, hypothesized to be of Saint John River ancestry, and thus considered evidence of the continued existence of the native stock. Successful recruitment of strong year classes of striped bass within the Saint John River, however, appears to be infrequent. We acoustically tagged and tracked juvenile and subadult striped bass ( $\mathrm{n}=37$; age 2-4) in the Saint John River in both 2015 and 2016, and identified summer feeding and overwintering habitats that established an in-river residency. Following decades of poor or no recruitment, it is now imperative that managers quickly include monitoring of juvenile and sub-adult striped bass and protection of their habitats in the conservation and recovery efforts for Saint John River striped bass stock.
\end{abstract}

KEY WORDS: Striped bass - Saint John River - Acoustic tracking - Population genetics · Stock recovery

\section{INTRODUCTION}

In 2012, the Committee on the Status of Endangered Wildlife in Canada (COSEWIC) listed the Saint John River (SJR) striped bass as endangered as part of the Bay of Fundy Designatable Unit (COSEWIC 2012). This listing was a result of the apparent loss of recruitment in 2 of the 3 known striped bass spawning rivers within the Bay of Fundy: the SJR (New Brunswick) and the Annapolis River (Nova Scotia). The Shubenacadie River in Nova Scotia currently remains as the region's sole recognized spawning location (but see Andrews et al. 2020a).

Stock declines in the SJR attributed to unregulated commercial harvest occurring until 1978 (Andrews et al. 2017) likely compounded upon the impact to spawning habitats observed in the downstream vicinity of

${ }^{*}$ Corresponding author: sandrew2@unb.ca the large Mactaquac Dam following its completion in 1968 (Bradford et al. 2015, Andrews et al. 2017, 2020a). Concomitantly, there has been no evidence of spawning or recruitment through infrequent searches since the mid-1970s (Dadswell 1975, DFO 2007, Andrews et al. 2017).

Juvenile striped bass were last reported in the SJR in 1979 (M. J. Dadswell, 1982 memorandum to R. Wilson, Environmental Protection Service; reviewed in Andrews et al. 2017); however, age-1 striped bass were again captured in the river in 2014 and that year class was monitored annually thereafter (Andrews et al. 2020a). These juveniles could not be genetically matched to any known spawning stock and it was concluded that they originated from historic SJR stock (Leblanc et al. 2018, 2020, Andrews et al. 2020a). Juvenile striped bass typically remain in

() The authors 2020. Open Access under Creative Commons by Attribution Licence. Use, distribution and reproduction are unrestricted. Authors and original publication must be credited. 
their natal rivers for the first 2 yr of life (Fay et al. 1983, Greene et al. 2009) but can also disperse along coastal regions and among adjacent rivers as youngof-the-year (Douglas et al. 2001, Robinson et al. 2004). In this study, we used acoustic telemetry to track the year-round movements and residency, overwintering habitats, summer habitats, and temperature occupancy of juvenile and sub-adult striped bass of presumed SJR ancestry.

\section{MATERIALS AND METHODS}

\subsection{Study area}

This study was conducted in the lower SJR, New Brunswick, within a region extending from the Mactaquac Dam (Mactaquac Hydroelectric Generating Station) downstream $150 \mathrm{~km}$ to the Reversing Falls at the City of Saint John, where the river empties into the Bay of Fundy (Fig. 1). Tidal influence can be observed upriver $130 \mathrm{~km}$ from the river mouth with salinity penetrating $\sim 70 \mathrm{~km}$ upstream to the village of Gagetown (Carter \& Dadswell 1983, Fig. 1). The SJR is met by 4 large tributary lakes and bays: Grand Lake, Washademoak Lake, Belleisle Bay, and Kennebecasis Bay (Fig. 1); the latter 2 water bodies are subject to a moderate tidal influence $(\sim 60 \mathrm{~cm})$. Salinity in these water bodies ranges from near fresh surface waters to salinities of 2.5-4.6 ppt at a depths $>15 \mathrm{~m}$ in Belleisle Bay (Andrews et al. 2020b) and 1-10 ppt near the surface of the Kennebecasis Bay and Hampton Marsh to $20 \mathrm{ppt}$ at depths $>15 \mathrm{~m}$ (Carter \& Dadswell 1983), where significant deep-water (64 m) habitats are available. Washademoak has low levels of detectable salinity at depth ( 1 ppt depending on time of year; Carter \& Dadswell 1983).

\subsection{Tagging}

Juvenile (age-2) and sub-adult (age-3-4) striped bass, aged from scales (Andrews et al. 2020a; $\mathrm{n}=37$, total length range: $23.4-46 \mathrm{~cm}$, weight range: $135-$ $914 \mathrm{~g}$ ), were captured in the SJR by means of boat electrofishing in Fredericton $(2015, \mathrm{n}=3)$, commercial trap net in both upper $(2016, \mathrm{n}=12$ ) and lower (2015, n = 1) Grand Lake, and both angling and gill netting in Hampton Marsh (2015, n = 14; 2016, n = 7; see Table 1, Fig. 1). Captured striped bass were weighed, measured, and implanted intracoelomically with Vemco V8-4H ( $\mathrm{n}=34$, tag life: $246 \mathrm{~d})$ and V7-4H ( $\mathrm{n}=3$; tag life: $132 \mathrm{~d}$ ) acoustic tags (see Table 1 ) following surgical tagging procedures outlined in Wingate \& Secor (2007) using a $40 \mathrm{mg} \mathrm{l}^{-1}$ solution of 10-part ETOH:1-parts clove oil solution as anaesthetic. During tagging, a small $\left(0.5 \mathrm{~cm}^{2}\right)$ clip was also taken from the upper lobe of the caudal fin for genetic analysis and ancestry determination. Tag weight in water (range: $0.7-0.9 \mathrm{~g}$ ) was $<0.5 \%$ of fish weigh, and

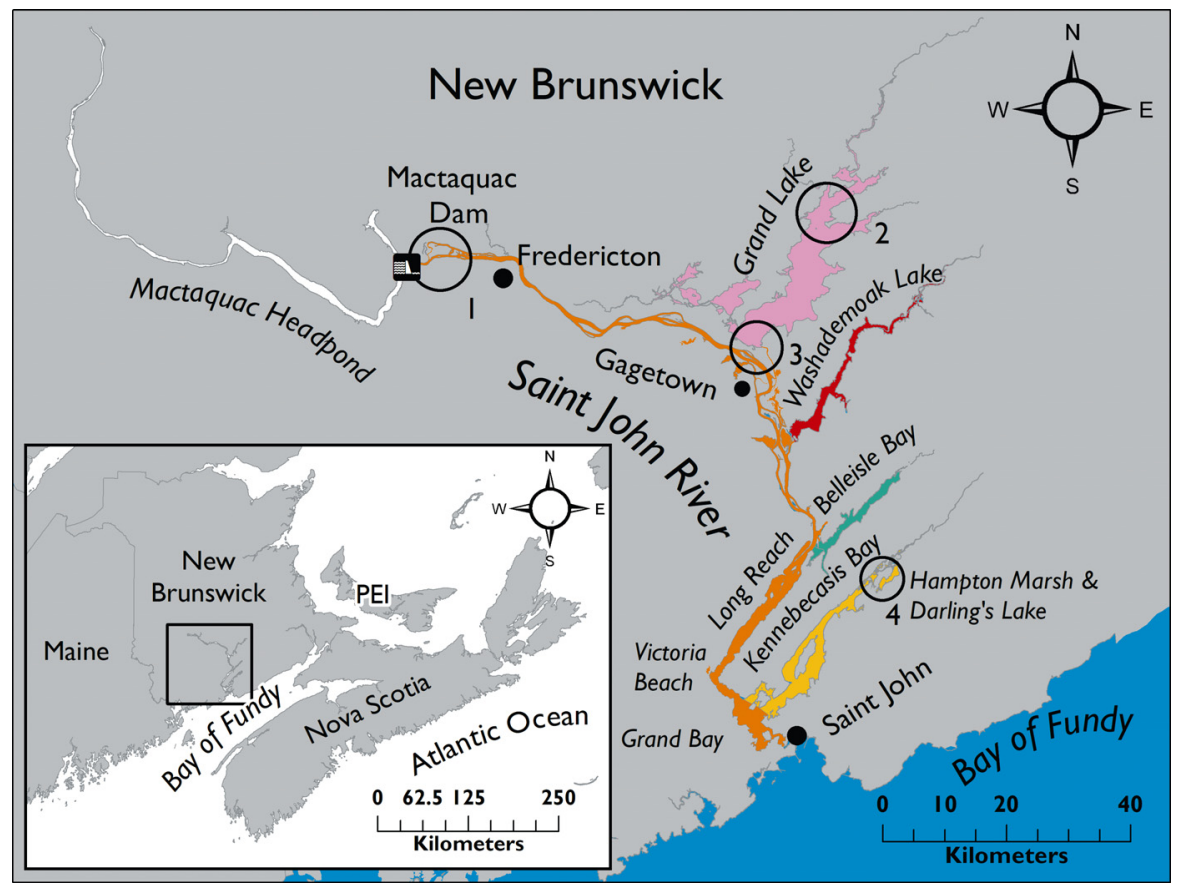

Fig. 1. Study area along the Saint John River, New Brunswick, ranging $150 \mathrm{~km}$ from the river mouth at the Bay of Fundy to the Mactaquac Dam. Numbered black circles indicate where juvenile striped bass were tagged (see Table 1). The colouration of the main river and tributaries are coordinated with Fig. 3 
all procedures were approved by the University of New Brunswick (UNB) Animal Care Committee (Animal Use Protocol Number 16026). All tagged striped bass were released at their location of capture once they re-gained muscle tone and the ability to maintain buoyancy following recovery from analgesia.

\subsection{Tracking and movement analysis}

Tagged striped bass were tracked with a Vemco VR2W passive receiver array distributed along the SJR from the river mouth at reversing falls to the Mactaquac Dam, including 2 units in the Saint John harbour in 2015 (Fig. 2). Receivers were anchored on the river bottom with concrete moorings and retrieved annually to offload data. The project-specific receiver array consisted of $\mathrm{n}=125$ receivers in 2015, 128 in 2016, and 64 in 2017 (recovered in summer 2018). Additional tag detections were received from the Ocean Tracking Network (OTN; http://oceantrackingnetwork.org/). OTN receivers detected tagged striped bass in the SJR in 2015 ( $n=15$ receivers) and 2016 ( $n=31$ receivers). Additionally, one OTN receiver was located in the Saint John Harbour at the river mouth that should have detected tagged striped bass if they left the river.

During analysis, each tag detection was assigned to a SJR zone (i.e. Main SJR, Grand Lake, Washademoak Lake, Belleisle Bay, Kennebecasis Bay), an 'outside SJR' zone was also created to account for any detection that could have occurred in the Bay of Fundy. Detection zones were then assigned colour codes (see Fig. 1), and daily area of occurrence by zone was plotted throughout the full extent of tag detections for each tagged striped bass for which sufficient data was available ( $\mathrm{n}=25$; see Fig. 3 ). If tagged striped bass were observed to alternate between zones within a single day, the zone where the individuals spent the longest time was that which was visually represented. If striped bass were not detected during a day or series of days, those individuals were considered to have remained in their last recorded zone of detection until a new detection suggested otherwise.

Throughout the tracking period, many projectspecific receivers were fitted with $\mathrm{HOBO}^{\circledR}$ (Onset) temperature pendants that recorded temperature $\left( \pm 0.1^{\circ} \mathrm{C}\right)$ every $30 \mathrm{~min}$ throughout deployment including $\mathrm{n}=91$ in 2015, 81 in 2016, and 40 in 2017 . These loggers recorded bottom temperatures at depths ranging $\sim 3-10 \mathrm{~m}$ where receiver moorings were deployed and were used to approximate the temperature residency of tagged striped bass. Dur-
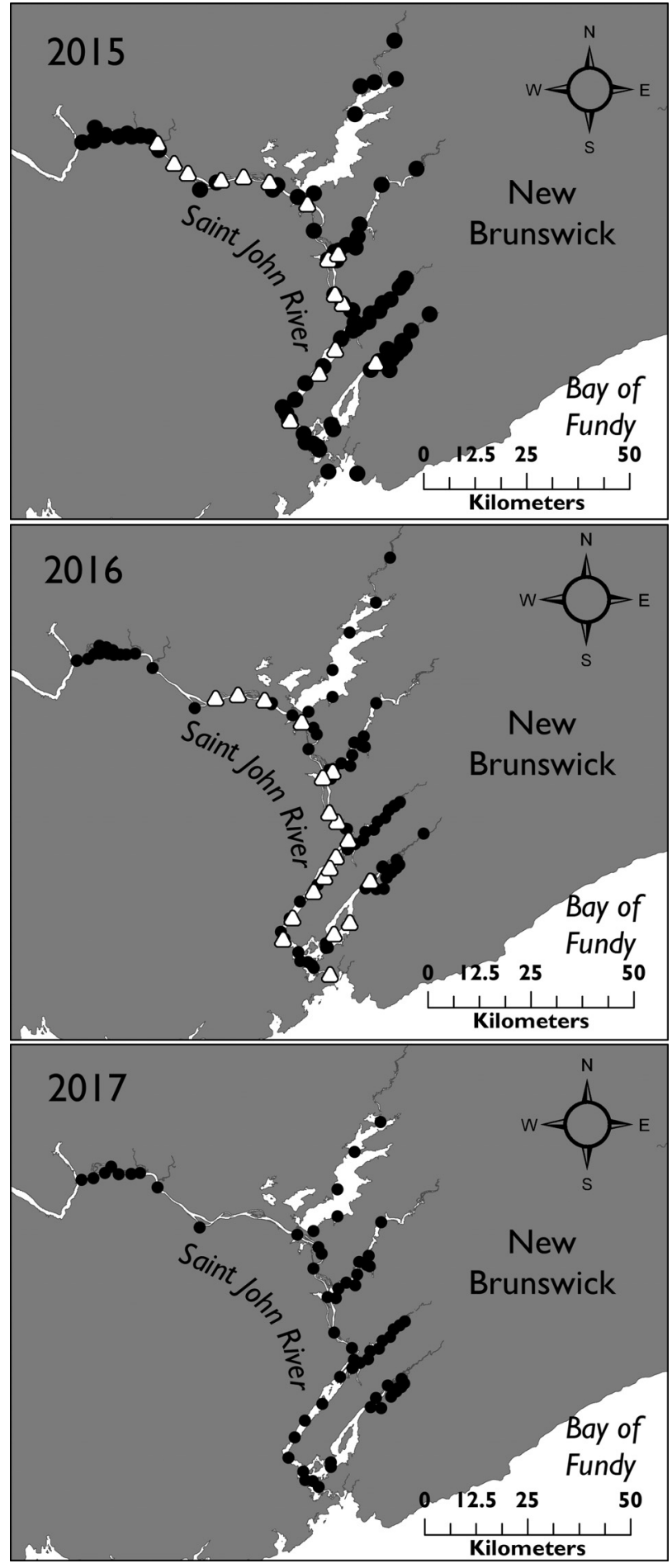

Fig. 2. Project-specific acoustic receivers (black circles), and Ocean Tracking Network receivers detecting tagged striped bass (white triangles) in the Saint John River from 2015-2017

ing analysis, temperature data recordings were matched to the nearest detection time when individual tagged juveniles and sub-adults were detected 
on corresponding receivers. Mean monthly temperatures were then calculated to describe thermal conditions of habitat occupancy where tagged striped bass occurred.

\subsection{Genetic characterization}

The genetic characteristics and ancestry classification of the tagged striped bass are described in detail in Leblanc et al. (2018). DNA was isolated from fin clips (SJR, Hudson River, Chesapeake Bay, and Miramichi individuals) or scales (Shubenacadie River individuals) using either the NucleoMag ${ }^{\circledR} 96$ Tissue kit (Machery-Nagel) or the E.Z.N.A Tissue DNA Kit (Omega Bio-Tek). Libraries of 96 samples each were constructed using a double digest restriction-site associated DNA sequencing protocol developed by Poland et al. (2012). We used restriction enzymes PstI and MspI to digest genomic DNA, and size-selected fragments using a Sage Pippin Prep@ $@$ platform at a size range of 377-523 bp. Libraries were processed using paired-end sequencing of $125 \mathrm{bp}$ with an Illumina ${ }^{\circledR} \mathrm{HiSeq}^{\mathrm{TM}} 2500$ at Génome Québec Innovation Centre.

Adapters were removed from genotyped sequences using Cutadapt v.1.13 (Martin 2011), and the 'process radtags' module found in Stacks v.1.46 (Catchen et al. 2013) was used to demultiplex and trim sequences to $110 \mathrm{bp}$. Demultiplexed sequences were aligned to the striped bass draft genome (BioProject accession no. PRJNA266827) using BWA v.0.7.15 (Li \& Durbin 2010), and then processed using the Stacks modules 'rxstacks', 'cstacks', 'pstacks', and 'stacks'. We used the 'snp' model type, and alpha of 0.1 , and a minimum log likelihood threshold of -40 . Using the Stacks module populations, loci were filtered to have a minimum read depth of 5 , no less than $20 \%$ missing data in each population, and loci that were not present in all populations. We removed single nucleotide polymorphisms

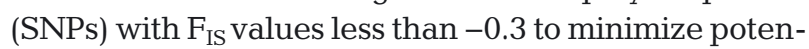
tial paralogs, and we also removed SNPs with minor allele frequencies less than 0.01 to control for possible sequencing errors. Individuals with more than $30 \%$ missing data were excluded from genetic analyses. Using the 'sNMF' function implemented in the R package LEA v.2.0 (Frichot \& François 2015), we estimated the number of genetic groups (or clusters) each individual in our study came from, and then assigned individuals to a cluster based on their ancestry coefficient. Individuals were said to belong to a cluster if they had an ancestry coefficient greater than 0.7 (70\%) for that cluster and were otherwise considered admixed.

\section{RESULTS}

\subsection{Juvenile ancestry}

Genetic characterization of juvenile and sub-adult striped bass collected within the SJR was unable to match 36 of the 37 sampled the individuals monitored in this study to any adjacent stock (i.e. Shubenacadie River, Miramichi River, Kennebec River, Hudson River, Chesapeake Bay; Leblanc et al. 2018, 2020) and thus they were determined to be of SJR ancestry (see Leblanc et al. 2018 for a complete evaluation; Table 1). A single age-4 individual was determined to be of Shubenacadie origin (this individual did not incur any detections post-tagging), while all others were assigned as either SJR ancestry ( $\mathrm{n}=24$, $67 \%$ ), admixed between fish of SJR and US ancestry ( $\mathrm{n}=11,30 \%$ ), or admixed between fish of SJR and Shubenacadie River ancestry $(\mathrm{n}=1,3 \%)$. All 3 of these groups, including both pure and admixed individuals demonstrating SJR ancestry, were considered to have originated from spawning events occurring within the SJR as adult striped bass sharing the presumed SJR ancestry have yet to be detected departing from the SJR (Andrews et al. 2020a,b; 7 yr of continuous acoustic tracking)

\subsection{Summer habitats and fall migration}

Of 37 tagged juveniles and sub-adult striped bass, $25(68 \%)$ incurred a high frequency of detections (>3000 across a detection period lasting 142-362 d), providing information on seasonal movements and habitat use (Table 1). Of striped bass tagged in Hampton Marsh in fall 2015 ( $\mathrm{n}=13), 8$ (62\%) exhibited a flight response immediately departing the region and travelled directly to winter habitats. Three individuals (23\% of those tagged in Hampton Marsh in 2015) remained in the area for 13-40 d following tagging prior to departing the area between 4 and 25 October (temp. range: $13-8.5^{\circ} \mathrm{C}$ ) to seek winter habitats. Two additional individuals (tag IDs: 37071 and 37072) remained within the region occupying Darling's Lake during the winter period and re-occupied Hampton Marsh in spring, never departing the Kennebecasis during the study period. Tagged striped bass ( $\mathrm{n}=9$ ) from the 2015 tagging group that departed from the Hampton Marsh in fall returned to the area in spring 2016 (8 May to 3 June) when water temperatures ranged from $11.5-19^{\circ} \mathrm{C}$.

Two sub-adult striped bass tagged in Grand Lake in spring 2016 (tag IDs: 37066 and 37060) travelled to 
Table 1. Acoustically tagged juvenile (age-2) and sub-adult (age-3-4) striped bass that produced high-frequency detection data ( $\mathrm{n}=25$ out of 37 tagged) along with tag data, date, location, days tracked, number of detections, biometrics, genetic origin, and winter location. The listed tagging locations match the numbered circles in Fig. 1: Fredericton (1), Grand Lake (2), Hampton Marsh (4). The single striped bass tagged in Lower Grand Lake (3) did not incur sufficient detections for inclusion in this table. Genetic ancestries are indicated as SJR: Saint John River; SJR/US: Saint John River/US admixed; SJR/SHU: Saint John River/Shubenacadie admixed (Leblanc et al. 2018); TL: total length; -: missing value

\begin{tabular}{|c|c|c|c|c|c|c|c|c|c|c|c|}
\hline $\begin{array}{l}\text { Tag } \\
\text { ID }\end{array}$ & $\begin{array}{l}\text { Tag } \\
\text { type }\end{array}$ & $\begin{array}{l}\text { Tagging } \\
\text { date }\end{array}$ & $\begin{array}{l}\text { Tagging } \\
\text { location }\end{array}$ & $\begin{array}{l}\text { Capture } \\
\text { method }\end{array}$ & $\begin{array}{c}\text { Days } \\
\text { tracked }\end{array}$ & Detections & $\begin{array}{c}\mathrm{TL} \\
(\mathrm{cm})\end{array}$ & $\begin{array}{l}\text { Weight } \\
\text { (g) }\end{array}$ & Age & $\begin{array}{l}\text { Genetic } \\
\text { ancestry }\end{array}$ & $\begin{array}{c}\text { Winter } \\
\text { location }\end{array}$ \\
\hline 35323 & $\mathrm{~V} 8-4 \mathrm{H}$ & 2015-08-25 & Hampton Marsh & Angling & 253 & 6326 & 27.0 & 181 & 2 & SJR/US & Long Reach \\
\hline 35324 & V8-4H & 2015-08-25 & Fredericton & Boat e-fishing & 250 & 7546 & 28.5 & 245 & 2 & SJR & Belleisle Bay \\
\hline 35325 & V8-4H & 2015-08-25 & Fredericton & Boat e-fishing & 251 & 51151 & 25.7 & 179 & 2 & SJR & Belleisle Bay \\
\hline 35322 & V8-4H & 2015-10-04 & Hampton Marsh & Angling & 251 & 31142 & 34.5 & 419 & 2 & SJR & Belleisle Bay \\
\hline 37070 & V8-4H & 2015-10-04 & Hampton Marsh & Angling & 362 & 22551 & 35.0 & 406 & 2 & SJR & Belleisle Bay \\
\hline 37071 & V8-4H & 2015-10-04 & Hampton Marsh & Angling & 248 & 89210 & 35.0 & 432 & 2 & SJR & Darling's Lake \\
\hline 37072 & V8-4H & 2015-10-04 & Hampton Marsh & Angling & 250 & 44162 & 37.0 & 563 & 2 & SJR & Darling's Lake \\
\hline 35321 & $\mathrm{~V} 8-4 \mathrm{H}$ & 2015-10-04 & Hampton Marsh & Angling & 249 & 7976 & 46.0 & 914 & 4 & SJR/US & Grand Lake \\
\hline 35327 & V8-4H & 2015-10 11 & Hampton Marsh & Angling & 250 & 42272 & 37.0 & 504 & 3 & SJR & Washademoak \\
\hline 35320 & $\mathrm{~V} 8-4 \mathrm{H}$ & 2015-10 12 & Hampton Marsh & Angling & 251 & 9699 & 31.7 & 344 & 3 & SJR & Long Reach \\
\hline 37057 & $\mathrm{~V} 8-4 \mathrm{H}$ & 2015-10 13 & Hampton Marsh & Angling & 251 & 10400 & 32.3 & 366 & 3 & SJR/US & Long Reach \\
\hline 37062 & V8-4H & 2015-10-16 & Hampton Marsh & Gill net ( $6 \mathrm{~cm}$ mesh) & 1) 250 & 14104 & 32.5 & 387 & 2 & SJR & Belleisle Bay \\
\hline 37069 & V8-4H & 2015-10-16 & Hampton Marsh & Gill net $(6 \mathrm{~cm}$ mesh) & 1) 251 & 36149 & 35.0 & 582 & 2 & SJR/US & Belleisle Bay \\
\hline 37068 & V8-4H & 2015-10-17 & Hampton Marsh & Gill net $(6 \mathrm{~cm}$ mesh) & 1) 251 & 13947 & 33.6 & - & 2 & SJR & Belleisle Bay \\
\hline 37065 & V8-4H & 2015-10-20 & Hampton Marsh & Gill net ( $6 \mathrm{~cm}$ mesh) & 1) 249 & 9759 & 33.4 & 364 & 2 & SJR & Belleisle Bay \\
\hline 37059 & $\mathrm{~V} 8-4 \mathrm{H}$ & 2016-05-11 & Grand Lake & Commercial net & 251 & 8680 & 35.6 & 460 & 3 & SJR/US & Grand Lake \\
\hline 37060 & V8-4H & 2016-05-11 & Grand Lake & Commercial net & 251 & 11840 & 35.0 & 460 & 3 & SJR & Grand Lake \\
\hline 37066 & V8-4H & 2016-05-11 & Grand Lake & Commercial net & 256 & 27369 & 33.0 & 310 & 3 & SJR & Grand Lake \\
\hline 37056 & V8-4H & 2016-05-20 & Grand Lake & Commercial net & 250 & 7987 & 37.0 & 530 & 3 & SJR & Grand Lake \\
\hline 37063 & $\mathrm{~V} 8-4 \mathrm{H}$ & 2016-05-20 & Grand Lake & Commercial net & 251 & 6001 & 34.4 & 480 & 3 & SJR & Grand Lake \\
\hline 37064 & $\mathrm{~V} 8-4 \mathrm{H}$ & 2016-05-20 & Grand Lake & Commercial net & 213 & 3828 & 38.3 & 450 & 3 & SJR & Grand Lake \\
\hline 37054 & V8-4H & 2016-06-01 & Hampton Marsh & Gill net $(6 \mathrm{~cm}$ mesh) & 1) 249 & 17390 & 35.0 & 400 & 3 & SJR/SHU & J Belleisle Bay \\
\hline 43421 & V7-4H & 2016-06-08 & Hampton Marsh & Angling & 137 & 10411 & 33.0 & 330 & 3 & SJR/US & Unknown \\
\hline 43430 & V7-4H & 2016-06-08 & Hampton Marsh & Angling & 137 & 12374 & 35.0 & 400 & 3 & SJR & Unknown \\
\hline 43418 & V7-4H & 2016-06-16 & Hampton Marsh & Angling & 137 & 23608 & 36.0 & 420 & 3 & SJR/US & Unknown \\
\hline
\end{tabular}

Hampton Marsh following tagging. One of these individuals (tag ID: 37066) occupied the area from 4 July to 24 October 2016, departing Hampton Marsh for winter habitats in Grand Lake when waters cooled to $11.5^{\circ} \mathrm{C}$. The second individual (tag ID: 37060 ) only briefly visited Hampton Marsh from 2-4 August when temperatures averaged $25^{\circ} \mathrm{C}$. These 2 individuals returned to Grand Lake in late fall on 4 and 6 November 2016 respectively for the winter period, arriving in the lake when water temperature in that location ranged from $10-10.5^{\circ} \mathrm{C}$. Two individuals tagged in Hampton Marsh in 2016 (tag IDs: 43421 and 43430) were never detected leaving the region throughout the duration of tag life, while a third individual (tag ID: 43418) departed from the region on 2 October when water temperature was $14.5^{\circ} \mathrm{C}$, though incurred no fall or winter detections. Apart from full-time Kennebecasis residents (i.e. 37071, 37072, 43421, 43430), juvenile and sub-adult striped bass arrived in Hampton Marsh when water temperatures were $>8.5^{\circ} \mathrm{C}$, experiencing a maximum temperature of $26^{\circ} \mathrm{C}$ recorded on 25 August 2015 .
In 2016, four of the 6 sub-adult striped bass tagged in Grand Lake also exhibited a tagging flight response like striped bass tagged in Hampton marsh in 2015, where those individuals rapidly departed from the lake to an area $\sim 100 \mathrm{~km}$ downstream only to return to Grand Lake 33-60 d post-tagging. These returning individuals spent the remainder of their time during summer in Grand Lake and further remained within the lake for the winter season. Two juvenile striped bass (age-2; tag IDs: 35325 and 35324) were captured downstream of the Mactaquac Dam (Fig. 1) in 2015 when water temperatures were $\sim 22^{\circ} \mathrm{C}$ (25 August). Those 2 individuals remained directly downstream of Mactaquac Dam from the time of tagging until departing to downstream winter habitats in Belleisle Bay on 17 and 26 October, when water temperatures at Mactaquac Dam dropped to 13 and $15^{\circ} \mathrm{C}$ respectively. One sub-adult striped bass, tagged in Hampton Marsh in spring of 2016 (tag ID: 37054), travelled downstream to the main river and then upstream to Grand Bay (Fig. 1) directly following tagging and remained in that region for the sum- 


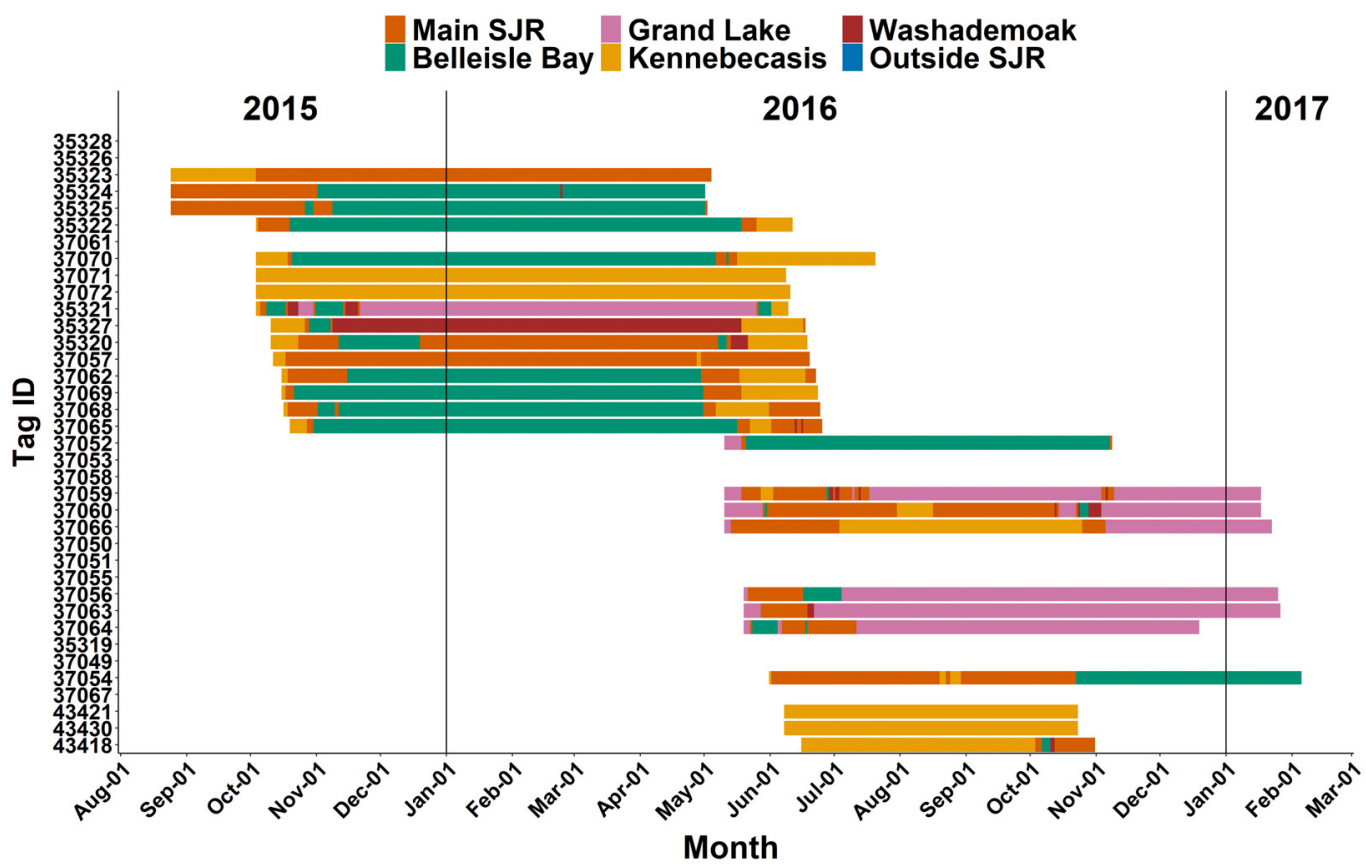

Fig. 3. Movements of individual juvenile striped bass (tag ID and individual bars) indicating their seasonal locations in the Saint John River from 2015-2017. Colours used to indicate area of occupancy in this figure match the colour-coded regions presented in Fig. 1. Note that no detections were incurred outside of the Saint John River

mer until moving to Belleisle Bay for the winter period, arriving on 10 November 2016.

\subsection{Winter habitats}

A total of 22 of the consistently detected juveniles $(88 \%)$ were observed through the winter (OctoberMay) in 5 different locations within the SJR (Fig. 3). They occupied Belleisle Bay $(\mathrm{n}=9,41 \% ; 20$ October to 19 May), Grand Lake ( $\mathrm{n}=7,32 \%, 24$ October 24 to 30 April), were sporadically detected in Long Reach near Victoria Beach $(\mathrm{n}=3,14 \%)$, Darling's Lake ( $\mathrm{n}=$ $2,9 \%$; 5 October to 23 April) adjacent to the Kennebecasis River, and Washademoak Lake $(\mathrm{n}=1,4 \%$; 9 November to 2 May). Juveniles $(n=6)$ that were tagged in and departed from Grand Lake in spring 2016 were detected re-entering Grand Lake in winter of that year.

In winter (1 December to $31 \mathrm{March}$ ), tagged striped bass occupied waters ranging from $0.2-2.2^{\circ} \mathrm{C}$ as measured at receiver locations which incurred detections in winter habitats (Fig. 4). These temperatures, however, may not accurately represent the true temperatures experienced by tagged striped bass occurring at different depths than the moored temperature loggers. Departure from winter habitats in spring 2016 occurred from 29 April to 19 May ( $\mathrm{n}=7$ obser- vations) from Belleisle Bay (temp. range: $6.5-9.5^{\circ} \mathrm{C}$ ), 30 April in Grand Lake ( $\mathrm{n}=1$ observation, temperature unknown), and 2 May in Washademoak Lake ( $\mathrm{n}=1$ observation, $7^{\circ} \mathrm{C}$ ).

All tagged striped bass of presumed SJR ancestry displayed a common movement pattern of travelling seasonally between apparent preferred summer and

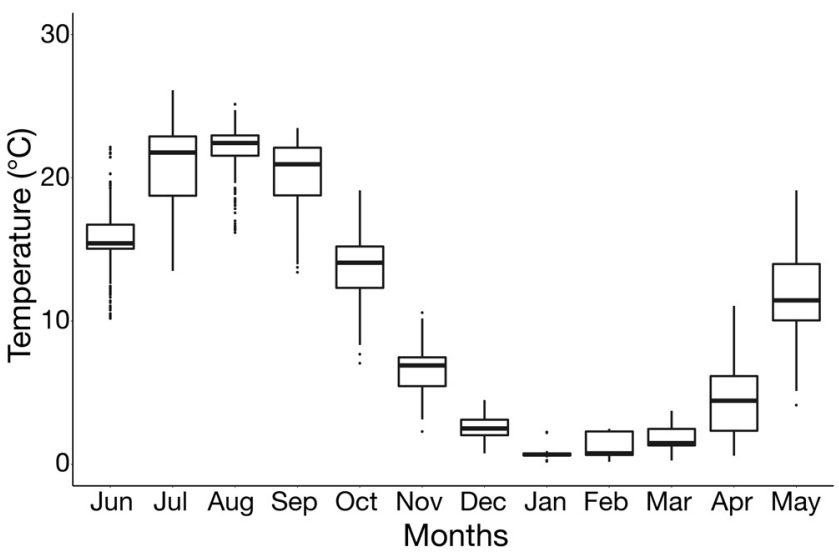

Fig. 4. Pooled, monthly water temperatures recorded on receivers bearing HOBO temperature loggers from 2014-2016 at the time when tagged striped bass were detected $(\mathrm{n}=$ 138570 observations). The upper and lower borders of each box represent the 25 th and 75 th percentile from the median represented by the center line. Solid boxplot whiskers extend to $1.5 \times$ the interquartile range with scattered points indicating outlying data 
winter locations (Figs. 1 \& 3). In summer, juvenile and sub-adult striped bass used areas in the Hampton Marsh in the uppermost reach of Kennebecasis Bay $(\mathrm{n}=15,60 \%)$ as well as a combination of Hampton Marsh and Long Reach ( $\mathrm{n}=3,12 \%)$, Grand Lake ( $\mathrm{n}=4,16 \%$ ), directly downstream of Mactaquac Dam (n=2,8\%), and Grand Bay ( $\mathrm{n}=1,4 \%$; Fig. 1). Hampton Marsh was used by the same 11 juveniles and sub-adults in 2 consecutive summers. Throughout the year, tagged striped bass occupied waters ranging from $0.2^{\circ} \mathrm{C}$ in winter to $26.1^{\circ} \mathrm{C}$ in summer (average $\pm 1 \mathrm{SD}: 10.4 \pm 7.8^{\circ} \mathrm{C}, \mathrm{n}=138570$ temperature readings; Fig. 4).

\section{DISCUSSION}

All juvenile striped bass (including SJR ancestry and admixed) tagged in this study remained within the river year-round (up to $362 \mathrm{~d}$ ), with no individuals being detected outside of the SJR at any point. Juvenile and sub-adult striped bass ( $\mathrm{n}=19,76 \%$ ) appeared to favour brackish and/or tidal marsh habitats during summer when water temperatures were $>8.5^{\circ} \mathrm{C}$. These habitats, i.e. Hampton Marsh, Grand Bay, and Long Reach (Fig. 1), are subject to a strong tidal influence up to $\sim 60 \mathrm{~cm}$ with surface salinities reaching 6.95 ppt (Reinhart 2018). This is consistent with summer habitat characteristics observed for other stocks (i.e. Albemarle Sound; Cooper et al. 1998, Mohan et al. 2015). Hampton Marsh has also been recognized as important habitat for adult striped bass in summer (Andrews et al. 2020a). Presumably, the juveniles and sub-adults are capitalizing on the area's abundant food resources, such as alewive Alosa pseudoharengus, blue back herring Alosa aestivalis, and many other young-of-the-year fishes such as yellow perch Perca flavescens, pumpkinseed sunfish Lepomis gibbosus, and lake chub Couesius plumbeus, all of which we have observed in juvenile striped bass stomachs in the SJR (Grand Lake and Hampton Marsh observations, see also Andrews et al. 2018). Six juvenile and sub-adult striped bass $(24 \%)$ were observed to occupy freshwater habitats in summer upstream of brackish water and in areas of minimal tidal influence (Grand Lake and the main river directly downstream of the Mactaquac Dam). Both areas are known to have large concentrations of juvenile river herring by late summer as well as many other abundant fishes (Curry \& Munkittrick 2005, Andrews et al. 2018) which would serve as a likely food source and reason to occupy these locations.
Juvenile and sub-adult striped bass departed from summer habitats moving towards apparent winter habitats in late fall (October) when river temperatures were $8.5-15^{\circ} \mathrm{C}$ depending on location. This temperature range corresponds closely to the temperatures when adult striped bass have been shown to shift to winter habitats, although the final departure date for adults occurred later in the fall in some years (Andrews et al. 2020b). Winter habitats overlapped with locations previously identified as adult habitat within the SJR (Andrews et al. 2020b) and these areas were occupied in similar proportions as the adults; i.e. predominantly in Belleisle Bay (41\%). Two juveniles were recorded in Long Reach in winter, a behaviour that has not been observed for adults. Long Reach is saline ( $\sim 7 \mathrm{ppt})$ with tides typically $>60 \mathrm{~cm}$, but the lower SJR can have complex, stratified temperature and saline conditions throughout deep ( 64 m) river sections (Reinhart 2018, Andrews et al. 2020a) and we have no accurate measurement of the direct winter conditions experienced by the juveniles due to logistical constraints in documenting physical habitat conditions in winter. The potential bias of tagging location and the possible influence on overwintering location occupancy could not be removed for the juveniles (see Andrews et al. 2020a). Nonetheless, like the tagged adults (Andrews et al. 2020a), most tagged juvenile and subadult striped bass spent their winter in Belleisle Bay despite none being tagged in that location.

In this study, we were able to track juveniles exiting Grand Lake in early spring and returning the next winter before tag batteries expired. This suggests that some juvenile striped bass $(100 \%$ of studied bass) re-occupied the same winter habitats between years, which is similar behaviour to adult striped bass in Grand Lake and other winter habitats in the SJR (Andrews et al. 2020a).

\section{CONCLUSIONS}

Juvenile striped bass were re-discovered in the SJR in 2014 following a 35 yr hiatus of recognition. Since then, the native SJR ancestry of these juveniles has been demonstrated (Leblanc et al. 2018), multi-year monitoring (6 yr) of a dominant 2013 year-class (which formed $84 \%$ of tagged juveniles in this study) has been conducted (Andrews et al. 2020a), and adults with SJR ancestry matching the ancestry of observed juveniles have been tracked to historic spawning grounds within the SJR (Andrews et al. 2017, 2020a). Tracking data presented in this study provides the final piece of evi- 
dence that observed juveniles are indeed of SJR ancestry, being the product of spawning events in the SJR in which striped bass of the SJR, Shubenacadie River, and US origin participate. These individuals (age 2-4), having been produced in the SJR, displayed consistent in-river residency, made use of a variety of seasonal habitats, and were never detected exiting the SJR at any time, thus precluding them from being possible migrants from some other stock.

Following these SJR studies, there remains no evidence that the juvenile striped bass observed within the SJR as first identified by Leblanc et al. (2018; particularly the 2013 year-class; Andrews et al. 2020a) originated anywhere but a spawning event of striped bass with SJR ancestry occurring within the SJR. We conclude that the observed juvenile bass are the result of the apparently infrequently successful striped bass spawning reported on the SJR (Bentzen \& Paterson 2008, Andrews et al. 2020a). Consequently, there is an emerging concern that these individuals and their habitats need immediate consideration for protection and continued monitoring to ensure some security of the SJR striped bass stock, which appears to have had no dominant year-class since 2013.

Effective conservation and recovery of striped bass in the SJR will depend on the immediate protection of the strong 2013 year-class described by Andrews et al. (2020a). These protections should include relief from fisheries exploitation, conservation of critical spawning, winter, and nursery habitats for all life stages, and review and discussion of hydropeaking operations at the Mactaquac Dam and their impact on spawning success of striped bass at this historic spawning ground (Andrews et al. 2020a). Canada's upcoming COSEWIC report on striped bass management must also clearly articulate the immediate need for conservation action on the SJR and highlight the ongoing lack of management response since the stock was first described as declining in the mid1970s (see Dadswell 1975, Andrews et al. 2017). Additionally, the SJR and the resident striped bass of unique genetic ancestry need quick consideration as a separate 'Designatable Unit' within the Bay of Fundy which currently includes the Shubenacadie, Saint John, and Annapolis rivers (see COSEWIC 2012). Importantly, proper designation would appropriately acknowledge the unique genetic ancestry, migratory patterns, and observed colonization and intermixing by striped bass of US ancestry in the SJR to adequately preserve genetic diversity (see Leblanc et al. 2018, Andrews et al. 2020a).
Acknowledgements. We thank the Wildlife Trust Fund F305-021 for funding the purchase of the V8 acoustic tags and the NSERC CRDPJ 462708 for providing the funding for the Vemco VR2W receiver array. We also sincerely thank Scott Young and his late father Keith Young for helping us to capture and tag juvenile striped bass at their commercial fishing operation on Grand Lake. This project could not have been completed without the hard work and incredible generosity of the Young family and the many dedicated fishermen who help them tend the nets each spring. Finally, we thank Chris Palmer, Lisa Rickard, Matt Miller, Mark Gautreau, and Eric Meng for their hard work in deploying and retrieving the project's large receiver array and for their help capturing and tagging the striped bass for this project.

\section{LITERATURE CITED}

Andrews SN, Linnansaari T, Curry RA, Dadswell MJ (2017) The misunderstood striped bass of the Saint John River, New Brunswick: past, present, and future. N Am J Fish Manage 37:235-254

Andrews SN, Zelman K, Ellis T, Linnansaari T, Curry RA (2018) Diet of striped bass and muskellunge downstream of a large hydroelectric dam: a preliminary investigation into suspected salmon smolt predation. N Am J Fish Manage 38:734-746

Andrews SN, Leblanc NM, Linnansaari T, Pavey SA, Curry RA (2020a) Interannual variation in spawning success and juvenile ecology of striped bass (Morone saxatilis) in the Saint John River, New Brunswick. River Res Appl 36: $13-24$

Andrews SN, Linnansaari T, Curry RA, Leblanc NM, Pavey SA (2020b) Winter ecology of striped bass (Morone saxatilis) near its northern limit of distribution in the Saint John River, New Brunswick. Environ Biol Fish 103:1343-1358

Bentzen P, Paterson IG (2008) Genetic analysis of striped bass collected by Kingsclear First Nation in the Saint John River, New Brunswick. Report to the Department of Fisheries and Oceans, Dartmouth

Bradford RG, Halfyard EA, Hayman T, LeBlanc P (2015) Overview of 2013 Bay of Fundy striped bass biology and general status. Can Sci Advis Sec Res Doc 2015/024. https://waves-vagues.dfo-mpo.gc.ca/Library/359709.pdf

Carter JCH, Dadswell MJ (1983) Seasonal and spatial distributions of planktonic Crustacea in the lower Saint John River, a multi-basin estuary in New Brunswick, Canada. Estuaries 6:142-153

* Catchen J, Hohenlohe PA, Bassham S, Amores A, Cresko WA (2013) Stacks: an analysis tool set for population genomics. Mol Ecol 22:3124-3140

COSEWIC (Committee on the Status of Endangered Wildlife in Canada) (2012) COSEWIC assessment and status report on the striped bass (Morone saxatilis) in Canada. Committee on the Status of Endangered Wildlife in Canada, Ottawa

Cooper JE, Rulifson RA, Isley JJ, Winslow SE (1998) Food habits and growth of juvenile striped bass, Morone saxatilis, in Albemarle Sound, North Carolina. Estuaries 21: 307-317

Curry RA, Munkittrick KR (2005) Fish assemblage structure in relation to multiple stressors along the Saint John River, New Brunswick, Canada. Am Fish Soc Symp 45: 505-521 
Dadswell MJ (1975) Mercury, DDT, and PCB content of certain fishes from the Saint John River estuary, New Brunswick. Transactions of the Atlantic Chapter, Canadian Society of Environmental Biologists annual meeting. Huntsman Marine Laboratory, St. Andrews, New Brunswick

DFO (Department of Fisheries and Oceans) (2007) Belleisle Bay fish and fish habitat. Can Sci Advis Sec Sci Res 2007/015. https://waves-vagues.dfo-mpo.gc.ca/Library/ 330721.pdf

Douglas SG, Chaput GC, Bradford RG (2001) Status of striped bass (Morone saxatilis) in the southern Gulf of St. Lawrence in 1999 and 2000. Can Sci Advis Sec Res Doc 2001/058. https://waves-vagues.dfo-mpo.gc.ca/Library/ 261841.pdf

Fay CW, Neves RJ, Pardue GB (1983) Species profiles: life histories and environmental requirements of coastal fishes and invertebrates (mid-Atlantic) - alewife/blueback herring. US Fish and Wildlife Service, Division of Biological Services Report No. FWS/OBS-82/11.9, and United States Army Corps of Engineers Report No. TR EL-82-4, Washington, DC. https://apps.dtic.mil/dtic/tr/fulltext/u2/ a181580.pdf

Frichot E, François O (2015) LEA: an R package for landscape and ecological association studies. Methods Ecol Evol 6:925-929

Greene KE, Zimmerman JL, Laney RW, Thomas-Blate J (2009) Atlantic coast diadromous fish habitat: a review of utilization, threats, recommendations for conservation, and research needs. Habitat Management Series No. 464. Atlantic States Marine Fisheries Commission, Washington, DC. https://www.asmfc.org/files/Habitat/HMS9_ Diadromous_Habitat_2009.pdf

Editorial responsibility: Uwe Krumme, Rostock, Germany
Leblanc NM, Andrews SN, Avery TS, Puncher GN and others (2018) Evidence of a genetically distinct population of striped bass within the Saint John River, New Brunswick, Canada. N Am J Fish Manage 38:1339-1349

* Leblanc NM, Gahagan BI, Andrews SN, Avery TS and others (2020) Genomic population structure of striped bass (Morone saxatilis) from the Gulf of St. Lawrence to Cape Fear River. Evol Appl 13:1468-1486

* Li H, Durbin R (2010) Fast and accurate long-read alignment with Burrows-Wheeler transform. Bioinformatics 26: 589-595

*Martin M (2011) Cutadapt removes adapter sequences from high-throughput sequencing reads. EMBnet J 17 : $10-12$

*Mohan JA, Halden NM, Rulifson RA (2015) Habitat use of juvenile striped bass Morone saxatilis (Actinopterygii: Moronidae) in rivers spanning a salinity gradient across a shallow wind-driven estuary. Environ Biol Fishes 98: 1105-1116

* Poland JA, Brown PJ, Sorrells ME, Jannink JL (2012) Development of high-density genetic maps for barley and wheat using a novel two-enzyme genotyping-bysequencing approach. PLOS ONE 7:e32253

Reinhart B (2018) Mercury in fish and invertebrates in the Saint John River estuary. MSc dissertation, University of New Brunswick, Saint John

Robinson M, Courtenay S, Benfey T, Maceda L, Wirgin I (2004) Origin and movement of young-of-the-year striped bass in the southern Gulf of St. Lawrence, New Brunswick. Trans Am Fish Soc 133:412-426

*Wingate RL, Secor DH (2007) Intercept telemetry of the Hudson River striped bass resident contingent: migration and homing patterns. Trans Am Fish Soc 136:95-104

Submitted: May 6, 2020; Accepted: September 3, 2020 Proofs received from author(s): October 22, 2020 